\title{
PENGEMBANGAN E-MODULE INTERAKTIF BERBASIS PROBLEM BASED LEARNING PADA MATERI KUBUS DAN BALOK KELAS VIII SMP
}

\author{
Yuyun Andika \\ (Mahasiswa Program Studi Pendidikan Matematika FKIP Universitas Islam Malang) \\ E-mail: andikayuyun@yahoo.com
}

\begin{abstract}
Abstrak
Tujuan pengembangan ini adalah tersusunnya e-module interaktif berbasis ProblemBased Learning materi kubus dan balok kelas VIII SMP. Pengembangan $e$-module interaktif ini mengunakan model 4-D yang meliputi 4 tahap yaitu define, design, develop, dan dissemminate. Produk yang dihasilkan berupa $e$ module interaktif yang telah divalidasi. Validator ahli media menyatakan valid dengan skor 3,3, ahli materi meyatakan valid dengan skor 3,52, ahli praktisi menyatakan valid dengan skor 3,16. Sedangkan hasil uji coba user menyatakan bahwa modul valid dengan skor 3,1. Dengan demikian, dapat disimpulkan bahwa modul yang dikembangkan sudah valid untuk digunakan dalam pembelajaran.
\end{abstract}

Kata Kunci: Pengembangan, e-module, interaktif, Problem Based Learning, kubus dan balok

\section{PENDAHULUAN}

Pendidikan merupakan hal yang sangat fundamental dalam meningkatkan kualitas kehidupan manusia dan menjamin perkembangan pembangunan bangsa. Salah satu pembaharuan yang dilakukan pemerintah adalah pembaharuan dalam proses pembelajaran yang menekankan pada penguasaan konsep materi secara tuntas untuk bisa melangkah ke materi selanjutnya.

Seiring perkembangan ilmu pengetahuan dan teknologi, saat ini modul tidak hanya berupa cetak. Pemanfaatan teknologi komputer dalam pembelajaran sangat mendukung adanya modul elektonik (e-module). Berdasarkan analisis kebutuhan guru dan siswa yang dilakukan di MTs Ainul Yaqin An-Nurhafi Lumajang diperoleh informasi bahwa pembelajaran matematika di MTs Ainul Yaqin An-Nurhafi Lumajang selama ini sudah menggunakan pembelajaran elektronik, salah satunya adalah penggunaan media power point. Namun media power point kurang efektif sebab media power point yang disajikan hanya memuat materi pembelajaran, untuk itu perlu adanya media pembelajaran yang efektif, efisien, serta menyenangkan. Salah satu media pembelajaran yang efektif dan menyenangkan adalah $e$-module intraktif.

Pembelajaran berbasis Problem Based Learning (PBL) merupakan pembelajaran yang penyampaiannya dilakukan dengan cara menyajikan suatu permasalahan, mengajukan pertanyaanpertanyaan, menfasilitasi penyelidikan, dan membuka dialog (Sani, 2015:127).

Penelitian ini bertujuan untuk tersusunnya e-module interaktif berbasis Problem Based Learning materi kubus dan balok kelas VIII SMP.

\section{Media Pembelajaran}

Pengembangan adalah proses atau langkah-langkah mengembangkan dan menyempurnakan produk yang telah ada menjadi baik dan sempurna. Pengembangan ini juga dapat diartikan sebuah proses membuat suatu produk terbaru.

Selanjutnya membahas tentang bahan ajar. Bahan ajar adalah segala bentuk bahan yang digunakan untuk membantu pendidik/instruktur dalam melaksanakan kegiatan belajar mengajar (Majid, 2011:173). National Centre For Competency Based Training (dalam Prastowo, 2012:16) 
mengemukakan bahwa bahan ajar merupakan informasi, alat dan teks yang diperlukan guru atau instruktur untuk perencanaan dan penelaahan implementasi pembelajaran.

Dari beberapa pengertian tersebut, dapat disimpulkan bahwa bahan ajar adalah seperangkat sarana yang berisikan materi pembelajaran, metode, batasan-batasan, dan cara mengevaluasi yang didesain secara sistematis dan menarik dalam rangka mencapai tujuan yang diharapkan, yaitu kompetensi dan sub kompetensi dengan segala kompleksitasnya.

\section{E-module}

E-module adalah salah satu cara terapan teknologi informasi dan komunikasi dalam proses pembelajaran. Menurut TIM P2M LPMM UNS (2012:2) e-module merupakan alat atau sarana pembelajaran yang berisis materi, metode batasan-batasan, dan cara mengevaluasi yang dirancang secara sistematis dan menarik untuk mencapai kompetensi yang diharapkan sesuai dengan tingkat kompleksitasnya secara elektronik dan bagian dari $e$ - learning.

Dari beberapa definisi para ahli di atas, dapat disimpulkan bahwa multimedia adalah perpaduan antara berbagai media berbasis komputer yang berupa teks, gambar, audio, animasi, dan video yang dapat memudahkan pengguna dalam menerima dan menyampaikan pesan kepada publik.

\section{Interaktif}

Menurut Prastowo (2014:328-329) kata "interaktif" mengandung arti bersifat saling melakukan aksi atau antar hubungan atau saling aktif. Dengan demikian, bahan ajar interaktif dapat dimaknai sebagai bahan ajar yang bersifat aktif, maksudnya bahan ajar dapat didesain agar dapat melakukan perintah balik kepada pengguna untuk melakukan suatu aktivitas.

Jadi, $e$-module interaktif merupakan $e$-module yang berisikan rangkaian kegiatan pembelajaran dalam suatu materi tertentu yang disusun secara sistematis, operasional, dan terarah untuk membantu siswa mencapai sejumlah tujuan yang dirumuskan secara khusus dan jelas yang digunakan dengan atau tanpa bimbingan pendidik dengan tingkat kompleksitasnya secara elektronik untuk mengkombinasikan beberapa media pembelajaran yang bersifat interaktif untuk mengendalikan suatu perintah atau perilaku alami dari suatu presentasi.

\section{Problem Based Learning}

Problem Based Learning merupakan pembelajaran yang menyampaikan dilakukan dengan cara menyajikan suatu permasalahan, mengajukan pertanyaan-pertanyaan, memfasilitasi penyelidik, dan membuka dialog.

Jadi, e-module interaktif berbasis Problem Based Learning merupakan $e$-module yang berisikan rangkaian kegiatan pembelajaran yang melibatkan siswa untuk memecahkan masalah nyata bagi siswa dalam suatu materi tertentu yang disusun secara sistematis, operasional, dan terarah untuk membantu siswa mencapai sejumlah tujuan yang dirumuskan secara khusus dan jelas yang digunakan dengan atau tanpa bimbingan pendidik, dengan tingkat kompleksitasnya secara elektronik untuk mengkombinasikan beberapa media pembelajaran yang bersifat interaktif untuk mengendalikan suatu perintah atau perilaku alami dari suatu presentasi.

\section{METODE}

E-module interaktif berbasis Problem Based Learning ini dikembangkan dengan model pengembangan 4-D yang diadaptasi dari Thiagarajan, Semmel dan Sammal. Model pengembangan ini terdiri dari 4 tahapan yaitu define, design, develop, dan disemminate.

Jenis data dalam pengembangan ini terdiri atas dua macam yaitu data kualitatif yakni data yang diperoleh dari komentar, kritik dan saran pada lembar validasi data, serta kuantitatif yakni skor penilaian yang ditulis pada angket yang mengenai kulitas kevalidan media pembelajaran yang dikembangkan. Teknik analisi data disesuaikan dengan data yang ada. Data kualitatif diperoleh dari perhitungan skor pada angket, sedangkan data kualitatif berupa kritika dan saran yang langsung ditulis oleh ahli media, ahli materi dan ahli praktisi dilembar validasi kritik dan saran yang berupa 
evaluasi kebenaran media, bagian yang salah, dan saran perbaikan media pembelajaran yang diisi oleh validator ahli, praktisi dan user.

Lokasi yang digunakan dalam penelitian ini yaitu MTs Ainul Yakin An-Nurhafi Lumajang. pengembangan ini melibatkan 1 guru kelas VIII MTs Ainul Yakin An-Nurhafi Lumajang Subjek uji coba pengembangan ini yaitu 9 siswa kelas VIII MTs Ainul Yakin An-Nurhafi Lumajan.

a. Tahap Define

Tujuan tahap ini adalah menetapkan dan mendefinisikan syarat-syarat pembelajaran,

b. Tahap Desain

Analisis tugas adalah kumpulan prosedur untuk menentuan isi dalam satuan pembelajaran,

c. Tahap Develop

Tujuan tahap ini adalah untuk menghasilkan perangkat pembelajaran yang sudah di revisi berdasarkan masukan dari para pakar,

d. Tahap Disseminate

Tahap ini merupakan tahap penggunaan perangkat yang telah dikembangkan pada skala yang lebih luasmisalnya di kelas lain, di sekolah lain, dan guru yang lain.

\section{HASIL}

\section{Pengembangan Produk}

Hasil dari pengembangan ini berupa e-module interaktif berbasis ProblemBased Learning materi kubus dan balok kelas VIII SMP . Materi dan latihan soal pada media pembelajaran ini disesuaikan dengan Kurikulum Tingkat Satuan Pendidika (KTSP).

Materi yang dibahas dalam media pembelajaran ini adalah materi kubus dan balok. Kompetensi Dasar (KD) yang dikaji yaitu mengidentifikasi sifat-sifat kubus dan balok, membuat jaring-jaring kubus dan balok, serta menghitung luas permukaan dan volume kubus dan balok. Tahap yang dilakukan adalah tahap define meliputi kebutuhan guru dan siswa, analisis guru, analisis siswa, analisis materi, analisi konsep, dan perumusan tujuan. Selanjutnya adalah tahap design, yaitu membuat desain multimedia dalam bentuk flowchart dan storynoard,. Pada tahap develop dilakukan uji validasi draf awal media pembelajaran kepada validator ahli, praktisi dan user. Sedangkan tahap disemminate belum terlaksana karena keterbatasan waktu dan biaya.

Media pembelajaran ini secara umum terdiri dari 5 bagian. Berikut tampilan bagain media pembelajara.

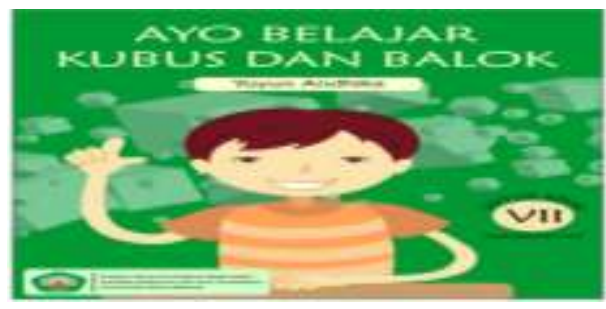

Gambar 1 Tampilan Utama

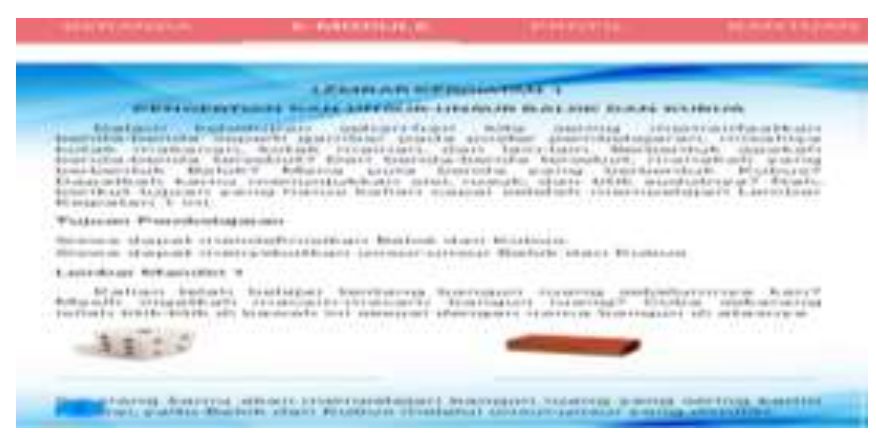

Gambar 2 Tampilan Materi Kubus dan Balok 


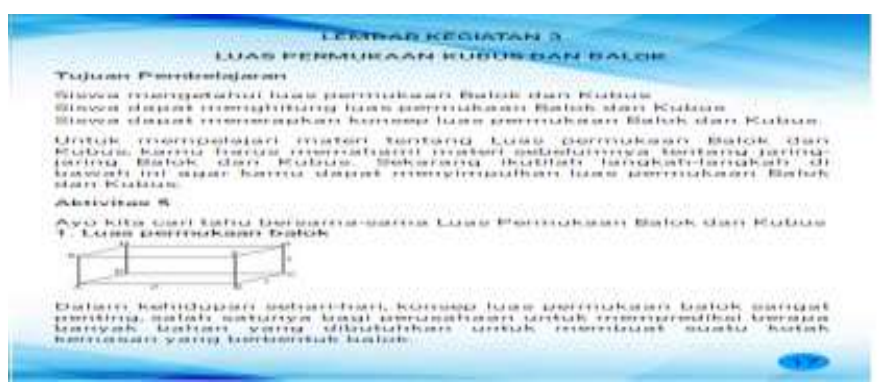

\section{Gambar 4 tampilan Materi Luas Permukaan Kubus dan Balok}

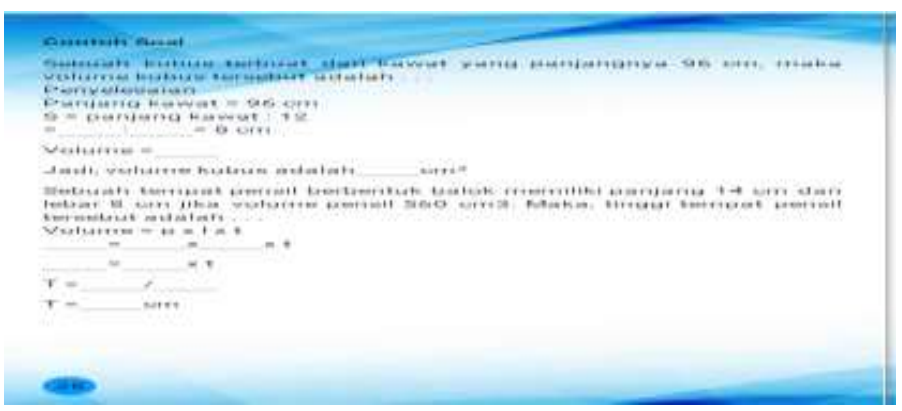

Gambar 4.9 Tampilan Soal Berbasis Problem Based Learning

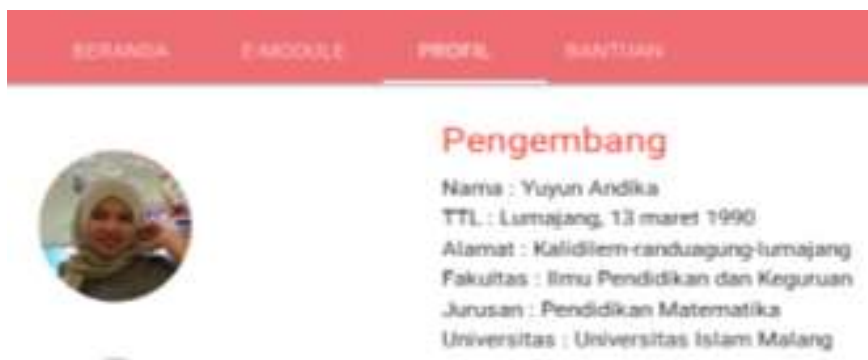

Bagian Profil Pengembang

\section{Telaah Ahli}

Pada uji validasi media pembelajaran, terdiri dari validator ahli media, validator ahli materi, dan validator praktisi. Uji coba user dengan skala kecil kepada siswa yaitu MTs Ainul Yakin AnNurhafi Lumajang. Berikut adalah hasil validasi ahli, praktisi, dan user.

1. Hasil Validasi Ahli Media skor rata-rata yang diperoleh dari aspek isi adalah 3,3, skor ratarata yang diperoleh dari aspek tampilaadalah adalah adalah 3,2, skor rata-rata yang diperoleh dari aspek pembelajaran adalah 3,3, jumlah keseluruhan skor ahli media adalah 3,3 dan dinyatakan valid.

2. Hasil Analisis Ahli Materi skor rata-rata yang dipyang dipoleh dari aspek materi ad alah 3,6, skor rata-rata yang dipyang dipoleh dari aspek soal latihan materi ad alah 3,5, skor rata-rata yang dipyang dipoleh dari aspek kebahasaanad alah 3,2, skor rata-rata yang dipyang dipoleh dari aspek tampilan ad alah 3,3, skor rata-rata yang dipyang dipoleh dari aspek pembelajaran ad alah 4,0, jumlah keseluruhan skor ahli materi adalah 3,52 dan dinyatakan valid.

3. Hasil Analisis Praktisi skor rata-rata yang dipyang dipoleh dari aspek materi ad alah 3,1, skor rata-rata yang dipyang dipoleh dari aspek soal latihan ad alah 3, 2, skor rata-rata yang dipyang dipoleh dari aspek kebahasaanad alah 3,2, skor rata-rata yang dipyang dipoleh dari aspek tampilan ad alah 3,3, skor rata-rata yang dipyang dipoleh dari aspek pembelajaran ad alah 3,0, jumlah keseluruhan skor ahli praktisis adalah 3,16 dan dinyatakan valid. 
4. Analisis Data Kelompok Validasi Ahli dan Praktisi skor rata-rata yang dipyang dipoleh dari ahli mediaadalah 3,3, skor rata-rata yang dipyang dipoleh dari ahli materi ad alah 3,52, skor rata-rata yang dipyang dipoleh dari ahli praktisi ad alah 3,16, jumlah keseluruhan skor para ahli adalah 3, 3 dan dinyatakan valid.

Berdasarkan hasil uji validasi, pengembangan E-module interaktif dengan skor rata-rata yang diperoleh dari validasi ahli media 3,3 (valid), validasi ahli materi 3,52 (valid), dan validasi praktisi 3,3 (valid), serta nilai rata-rata analisis data kelompok dari semua validator adalah 3,46 (valid), sehingga dapat disimpulkan bahwa berbasis Problem Based Learning pada materi kubus dan balok kelas VIII SMP adalah valid dan dapat digunakan.

Setelah media pembelajaran divalidasi oleh validator ahli dan praktisi, selanjutnya diujicobakan kepada siswa dalam ujicoba skala kecil, yaitu 9 siswa MTs Ainul Yakin An-Nurhafi Lumajang.

5. Hasil Analisis Data Kelompok Ujicoba User skor rata-rata yang dipyang dipoleh dari uji pengguna siswa berkemampuan baik adalah 3,2, skor rata-rata yang dipyang dipoleh dari uji pengguna siswa berkemampuan sedang ad alah 3,1, skor rata-rata yang dipyang dipoleh dari uji pengguna siswa berkemampuan kurang ad alah3,0, jumlah keseluruhan skor uji coba user adalah 3,1, dan dinyatakan valid.

Berdasarkan tabel tersebut menunjukkan nilai rata-rata total dari semua kelompok pengguna adalah 3,1, sehingga data tersebut sesuai kriteria kevalidan. Dapat disimpulkan bahwa untuk $e$ module interaktif berbasis Problem Based Learningdinyatakan valid.

\section{Tanggapan Siswa}

Dari hasil ujicoba didapatkan tanggapan kritik serta komentar dari siswa yaitu sebagai berikut: 1) Game adventure sangat menyenangkan dan tidak membosankan, serta $e$-module sangat menyenangkan dan tidak membosankan. Revisi Produk

Untuk mencapai produk yang medekati sempurna dan memenuhi target ketepatan, kelayakan, dan kegunaan produk, maka e-module interaktif berbasis Problem Based Learning materi kubus dan balok kelas VIII SMP ini melewati beberapa revisi sampai pada hasil akhir yang berupa e-module interaktif berbasis Problem Based Learning yang siap digunakan. Beberapa revisi yang dilakukan adalah sebagai berikut: Cover yang lebih menarik, gambar pada materi diganti dengan gambar yang lebih menarik, daftar isi, kunci jawaban.

\section{PEMBAHASAN}

Seel \& Richey (dalam Setyosari, 2013: 226) mendefinisikan pengembangan sebagai proses menerjemahkan atau menjabarkan spesifikasi rancangan ke dalam bentuk fisik, atau dengan kata lain, pengembangan berarti rancangan menghasilkan bahan-bahan pembelajaran. Dalam pengembangan ini pengembang menghasilkan e-module interaktif berbasis Problem Based Learning pada pokok bahasan kubus dan balok. Desain yang dihasilkan berupa software berupa $e$ module. Media ini dikemas dalam bentuk CD (Compact Disk). Hasil pengembangan yang diperoleh berupa e-module interaktif berbasis Problem Based Learning, materi kubus dan balok. Di dalam e-module terdapat latihan soal berbasis Problem Based Learning tersebut, profil pengembang, serta petunjuk penggunaan e-module. Dengan menggunakan media ini siswa dapat menyelesaikan soal-soal kubus dan balok serta siswa bisa menjadi lebih mudah memahami materi yang terdapat pada produk tersebut.

Hasil validasi analisis dari ahli media, materi, dan praktisi adalah 3,3, sehingga dapat diketahui bahwa media pembelajaran yang dikembangkan memiliki kriteria yang valid. Sedangkan analisis data hasil uji coba user yang dilakukan oleh 9 siswa kelas VIII di MTs Ainul Yakin AnNurhafi Lumajang diperoleh 3,1 dan dinyatakan valid untuk digunakan.

Dapat disimpulkan bahwa e-module pembelajaran berbasis Problem Based Learning layak untuk digunakan sebagai media pembelajaran matematika khususnya pada materi kubus dan balok. 


\section{SIMPULAN DAN SARAN}

Tujuan pengembangan ini adalah tersusunnya e-module interaktif berbasis ProblemBased Learning materi kubus dan balok kelas VIII SMP.Pengembangan e-module interaktif ini mengunakan model 4-D yang meliputi 4 tahap yaitu define, design, develop, dan dissemminate. Produk yang dihasilkan berupa e-module interaktif yang telah divalidasi. Validator ahli media menyatakan valid dengan skor 3,3, ahli materi meyatakan valid dengan skor 3,52, ahli praktisi menyatakan valid dengan skor 3,16. Sedangkan hasil uji coba user menyatakan bahwa modul valid dengan skor 3,1. Dengan demikian, dapat disimpulkan bahwa modul yang dikembangkan sudah valid untuk digunakan dalam pembelajaran.

\section{DAFTAR RUJUKAN}

Majid, Abdul. 2011. Perencanaan Pembelajaran Mengembangkan Standar Kompetensi Guru. Bandung: Rosda Karya

Prastowo, Andi. 2012. Panduan Kreatif Membuat Bahan Ajar Inovatif. Yogyakarta: Diva Press

Prastowo, Andi. 2014. Panduan Kreatif Membuat Bahan Ajar Inovatif.

Sani, Abdullah, Ridwan. 2015.Pembelajaran Saintifik untuk Implementasi Kurikulum 2013.Jakarta: Bumi Aksara

Setyosari, Punaji. 2015. Metode Penelitian Pendidikan dan Pengembangan. Malang: Kencana Prenadamedia Group.

Trianto. 2007. Model Pembelajaran Terpadu dalam Teori dan Praktek. Surabaya: Pustaka Ilmu. 